\title{
Photocatalytic Degradation of Pesticides in Natural Water: Effect of Hydrogen Peroxide
}

\author{
Natividad Miguel, María P. Ormad, Rosa Mosteo, and José L. Ovelleiro \\ Department of Chemical Engineering and Environmental Technologies, University of Zaragoza, Pedro Cerbuna 12, \\ 50009 Zaragoza, Spain \\ Correspondence should be addressed to Natividad Miguel, nmiguel@unizar.es
}

Received 12 August 2011; Revised 20 November 2011; Accepted 1 December 2011

Academic Editor: Jae Sung Lee

Copyright (๑) 2012 Natividad Miguel et al. This is an open access article distributed under the Creative Commons Attribution License, which permits unrestricted use, distribution, and reproduction in any medium, provided the original work is properly cited.

\begin{abstract}
The aim of this paper is to evaluate the effectiveness of photocatalytic treatment with titanium dioxide in the degradation of 44 organic pesticides analyzed systematically in the Ebro river basin (Spain). The effect of the addition of hydrogen peroxide in this treatment is studied, and a monitoring of effectiveness of photocatalytic processes is carried out by measurements of physical-chemical parameters of water. The application of photocatalytic treatment with $1 \mathrm{~g} \mathrm{~L}^{-1}$ of $\mathrm{TiO}_{2}$ during 30 minutes achieves an average degradation of the studied pesticides of $48 \%$. Chlorine demand, toxicity, and dissolved organic carbon (DOC) concentration of water are reduced. If hydrogen peroxide is added with a concentration of $10 \mathrm{mM}$, the average degradation of pesticides increases up to 57\%, although chlorine demand and toxicity of water increase while DOC concentration remains unchanged with this treatment. The application of either photocatalytic treatments does not produce variations in the physicalchemical parameters of water, such as $\mathrm{pH}$, conductivity, colour, dissolved oxygen, and hardness. The pesticides which are best degraded by photocatalytic treatments are parathion methyl, chlorpyrifos, $\alpha$-endosulphan, 3,4-dichloroaniline, 4-isopropylaniline, and dicofol while the worst degraded are $\mathrm{HCHs}$, endosulphan-sulphate, heptachlors epoxide, and 4,4'-dichlorobenzophenone.
\end{abstract}

\section{Introduction}

During recent years, numerous organic substances considered to be hazardous have been detected in waters of Ebro river basin (Spain). These substances have been detected in surface and ground waters and they can be considered hazardous substances according to the current legislation because they are toxic, persistent, and bioaccumulative substances.

Pesticides, artificially synthesized substances used to fight pests and improve agricultural production, are especially problematic. These are monitored by the Pesticides Control Network (Ebro river basin), which systematically analyzes 44 organic pesticides in surface waters. These pesticides were selected because of their appearance in lists of hazardous substances and/or their high level of use in Spanish agriculture. The 44 pesticides analyzed in the Ebro river basin are alachlor, aldrin, ametryn, atrazine, chlorfenvinfos, chlorpyrifos, $\mathrm{pp}^{\prime}$-DDD, op' $\mathrm{p}^{\prime} \mathrm{DDE}, \mathrm{op}^{\prime}$-DDT, $\mathrm{pp}^{\prime}-\mathrm{DDT}$, desethylatrazine, 3,4-dichloroaniline, 4,4'-dichlorobenzophenone, dicofol, dieldrin, dimethoate, diuron, $\alpha$-endosulphan, endosulphan-sulphate, endrin, $\alpha-\mathrm{HCH}, \beta-\mathrm{HCH}$, $\gamma$-HCH, $\delta$-HCH, heptachlor, heptachlor epoxide A, heptachlor epoxide $\mathrm{B}$, hexachlorobenzene, isodrin, 4-isopropylaniline, isoproturon, metholachlor, methoxychlor, molinate, parathion methyl, parathion ethyl, prometon, prometryn, propazine, simazine, terbuthylazine, terbutryn, tetradifon, and trifluralin.

Due to the presence of hazardous substances, both natural water used to supply the population and water which is to be reused have to be treated in water treatment plants to ensure that they comply with the minimum criteria established in the current legislation [1-3].

Water treatments consist of several operations which often do not achieve the removal of hazardous substances or entail other problems deriving from the treatment.

In the case of drinking water production, an important successful development is the possible formation of 
organic-halogenated compounds, potentially carcinogenic and chlorinated deriving from methane, as reaction products between chlorine (common disinfectant product) and the organic matter in water. The most abundant of these are trihalomethanes (THMs) whose concentration is limited by Spanish Royal Decree 140/2003 at to $100 \mu \mathrm{g} \mathrm{L}-1$.

The drawbacks in the use of compounds with chlorine, among others, have derived in the research of other alternative treatments for removing pollutants in water treatments. Among these, advanced oxidation processes (AOPs) are based on the generation of reactive oxygen species, which are highly reactive, nonselective, and do not generate toxic byproducts $[4,5]$. These species are capable of degrading a substantial number of pollutants by radicalary mechanisms. The generation of these species can be carried out by processes with ozone, hydrogen peroxide, metallic catalysts, UV radiation, and so forth.

One of the most frequently investigated AOPs in recent years is the photocatalytic process. Photocatalysis entail the combination of radiation and catalyst. Both are necessary in order to achieve or accelerate a chemical reaction, and therefore photocatalysis can be defined as the "acceleration of a photoreaction by the presence of a catalyst."

Catalysts used in these processes are semiconductor metallic oxides materials. The surface of semiconductor metallic oxides provides a place where oxidation-reduction reactions can be started by radiation. Semiconductors have bands associated with energy levels spaced between them. Photoexcitation with energy equal to or greater than that of the gap between the valence and conduction bands moves an electron from the valence band to the conduction band, generating a hole deficient in electrons. The oxidation of an adsorbed molecule can be produced in holes and simultaneously the reduction of another molecule can be produced in the opposite part of the catalyst.

Numerous semiconductor substances have been tried as catalyst in photocatalytic processes. Generally, it is known that titanium dioxide is one of the most effective. Moreover, it has a high stability and photoactivity, low cost, nontoxicity, and solubility. The activation of titanium dioxide is produced with radiation at $\lambda<387 \mathrm{~nm}$.

As a result of the application of photocatalytic processes based on titanium dioxide, the number of references in the literature in recent decades related to the degradation of toxic and hazardous substances in water can be counted in their thousands. As regards the group of pesticides under study, photocatalytic processes have been applied in several ways and there are many references to the degradation of such pesticides such as triazines $[6,7]$, organic-phosphorated pesticides [8-10], alachlor $[11,12]$, diuron $[7,13]$, and parathion methyl [14].

The addition of hydrogen peroxide to photocatalytic treatment with titanium dioxide can be used to increase the effectiveness of the latter process because, as hydrogen peroxide is a more powerful oxidant than oxygen, it generates a larger collection of electrons and this avoids the recombination of electron-hole pairs formed in the photocatalytic process. Hydrogen peroxide is an electron acceptor and it can react with electrons in the conduction band and generate radicals.

Similarly, there are several references concerning the removal of pesticides by photocatalytic treatments with hydrogen peroxide, such as the degradation of atrazine, isoproturon, alachlor and diuron [7], organic-phosphorated pesticides $[9,10]$, and other triazines [15].

However, the results show a big disparity with respect to the effect of hydrogen peroxide. It is sometimes beneficial while at other times it is damaging to the effectiveness of the process. This phenomenon, the effect of hydrogen peroxide in photocatalytic treatments, produces additional drawbacks when complex mixtures of pollutants are used. The damaging effect in the degradation rate is produced by a modification of the catalyst surface by hydrogen peroxide adsorption [16] and the inhibition of generated holes in the valence band and reaction with hydroxyl radicals [17]. When the effect of hydrogen peroxide is beneficial, a substantial consumption of hydrogen peroxide is sometimes necessary in order to obtain only a small increment of the degradation rate.

The aim of this research work is to evaluate the degradation of the 44 pesticides systematically analyzed in the Ebro river by photocatalytic treatment with titanium dioxide and to study the effect of hydrogen peroxide in this treatment. Moreover, a monitoring of the effectiveness of the photocatalytic processes is carried out by measuring the physicalchemical parameters of water.

\section{Materials and Methods}

2.1. Samples. Samples of natural water from the Ebro river upstream from Zaragoza (Spain) were prepared by fortification with 44 pesticides in concentrations of $500 \mathrm{ng} \mathrm{L}^{-1}$. These 44 organic pesticides, listed in the introduction section, are systematically analysed in surface waters by the Network of Control of Pesticides in the Ebro river basin.

2.2. Sample Characterization. The characterization of the samples was carried out using the parameters shown in Table 1. The equipment used and standard methods applied are detailed below.

The analysis of the chromatographic conditions of the pesticides is shown in Table 2 and the results of the validation of this analysis in Table 3.

Previously to the analysis of pesticides by GC/MS a solidliquid extraction was carried out. This extraction consisted of the retention of organic compounds in a solid phase and subsequent elution with an organic solvent.

The extraction was carried out using an AUTOTRACE WorkStation automatic extractor (Zymark). Before extraction, $100 \mathrm{ng} \mathrm{L}^{-1}$ of surrogate compounds used to control the extraction process (simazine-D5, atrazine-D5, and prometryn-D6) were added to the water sample. During solidliquid extraction, $900 \mathrm{~mL}$ of the sample was passed through cartridges containing a solid ENV+ filter (polystyrene divinyl benzene copolymer) (ISOLUTE cartridges, $200 \mathrm{mg}^{\mathrm{mL}} \mathrm{mL}^{-1}$ ). The pesticides contained in the sample were retained in 
TABLE 1: Parameters, equipment, and standardized methods used for the characterization of samples.

\begin{tabular}{|c|c|c|c|}
\hline Parameter & Equipment & Standard method & Reference \\
\hline $\mathrm{pH}$ and temperature & pH-meter CRISON GLP21 & SM 4500-HB & {$[18]$} \\
\hline Conductivity & Conductivity-meter CRISON Basic30 & $\begin{array}{c}\text { UNE-EN } \\
27888: 1994\end{array}$ & {$[19]$} \\
\hline $\begin{array}{l}\text { Dissolved organic carbon (DOC) } \\
\text { concentration }\end{array}$ & Analyzer Shimadzu TOC-VCSH & SM 5310B & {$[18]$} \\
\hline Chlorine Demand & - & SM 5710B & {$[18]$} \\
\hline Turbidity & Turbidity-meter Hanna LP2000 & ISO 7027: 1999 & {$[20]$} \\
\hline Color & Multiparametric Photometer Hanna C99 & SM 2120B & {$[18]$} \\
\hline Dissolved oxygen concentration & Multiparametric Photometer Hanna C99 & SM 4500-O C & {$[18]$} \\
\hline Hydrogen peroxide concentration & - & - & {$[21]$} \\
\hline Hardness & Multiparametric Photometer Hanna C99 & SM 2340B & {$[18]$} \\
\hline Suspended solids concentration & $\begin{array}{l}\text { Multiparametric Photometer Hach Lange } \\
\text { DR2800 }\end{array}$ & SM 2540D & {$[18]$} \\
\hline Phosporous concentration & Multiparametric Photometer Hanna C99 & SM 4500-P C & {$[18]$} \\
\hline Ammonia concentration & Multiparametric Photometer Hanna C99 & SM 4500-NH3 C & {$[18]$} \\
\hline Cyanide concentration & Multiparametric Photometer Hanna C99 & SM 4500-CN E & {$[18]$} \\
\hline $\begin{array}{l}\text { Fluoride, chloride, nitrate, phosphate, } \\
\text { and sulphate concentration }\end{array}$ & $\begin{array}{c}\text { Ionic Chromatographer DIONEX } \\
\text { ICS-1000 }\end{array}$ & SM 4110B & {$[18]$} \\
\hline Toxicity & Toxicity-meter LUMIStox 300 & ISO 11348: 1999 & {$[22]$} \\
\hline Pesticides & $\begin{array}{c}\text { Gas chromatographer TRACE2000 and } \\
\text { mass spectrometer POLARIS }\end{array}$ & EPA 525.2 & {$[23]$} \\
\hline
\end{tabular}

TABLE 2: Conditions of pesticide analysis.

\begin{tabular}{|c|c|}
\hline \multicolumn{2}{|r|}{ Gas chromatographer TRACE GC 2000 (Thermo Finnigan) } \\
\hline Column & DB5-MS (J\&W, $30 \mathrm{~m}, 0.25 \mathrm{~mm}, 0.25 \mu \mathrm{m})$ \\
\hline Program of temperatures & $90^{\circ} \mathrm{C}(1 \mathrm{~min}), 20^{\circ} \mathrm{C} \min ^{-1}, 180^{\circ} \mathrm{C}(1 \mathrm{~min}), 2^{\circ} \mathrm{C} \min ^{-1}, 240^{\circ} \mathrm{C}(1 \mathrm{~min}), 20^{\circ} \mathrm{C} \min ^{-1}, 310^{\circ} \mathrm{C}(10 \mathrm{~min})$ \\
\hline Injector temperature & $250^{\circ} \mathrm{C}$ \\
\hline Injection volume & $1 \mu \mathrm{L}$, splitless $0.8 \mathrm{~min}$ \\
\hline Carrier gas & He (N55), $1 \mathrm{~mL} \mathrm{~min}^{-1}$ \\
\hline \multicolumn{2}{|r|}{ Mass spectrometer POLARIS (Thermo Finnigan) } \\
\hline Ionization energy & $70 \mathrm{eV}$ \\
\hline Acquisition mode & Full scan \\
\hline Mass interval & $50-450 \mathrm{amu}$ \\
\hline Screen speed & 1 scan s $^{-1}$ \\
\hline Acquisition time & $32.5 \mathrm{~min}$ \\
\hline
\end{tabular}

the solid phase and dried under $N_{2}$ for 10 minutes. They were then eluted by passing $10 \mathrm{~mL}$ of ethyl acetate (SDS for pesticide analysis) through the cartridge, thus facilitating the passage of these compounds from the water phase to an organic phase. The extracts thus obtained were concentrated under a $\mathrm{N}_{2}$ flow until an approximate volume of $1 \mathrm{~mL}$ was obtained, after which $3 \mathrm{~mL}$ of isooctane was added (SDS for pesticide analysis) in order to carry out a change of solvent. The extract was then concentrated until obtaining an approximate volume of $0.5 \mathrm{~mL}$. Anthracene deuterate (D10, SUPELCO) was added to each extract as an internal standard for subsequent quantification of the pesticides present in the samples. These extracts were analysed by GC/MS.
2.3. Experimental Procedure in Photocatalytic Treatments. The titanium dioxide used in this work was Degussa P25. The tests were carried out with a dose of $1 \mathrm{gL}^{-1}$, the same as that used in previous studies and determined as optimal in the stages of disinfection [24-26]. The $\mathrm{TiO}_{2}$ was added to $1 \mathrm{~L}$ of sample to be treated and shaken at $300 \mathrm{rpm}$ to promote contact between the sample and the catalyst and provide oxygen to the reaction medium. The reaction time was 30 minutes.

For tests with hydrogen peroxide, the compound was added to the sample $\mathrm{H}_{2} \mathrm{O}_{2} 30 \%$ v/v (Carlo Erba) with a concentration of $10 \mathrm{mM}$. This same dose has been used and determined as optimal in many research works evaluating 
TABLE 3: Results of the methodology validation of the pesticide analysis.

\begin{tabular}{|c|c|c|c|c|c|c|}
\hline \multirow{2}{*}{ Pesticide } & \multicolumn{2}{|c|}{ Quantification limit $\left(\mu \mathrm{g} \mathrm{L}^{-1}\right)$} & \multirow{2}{*}{$\begin{array}{c}\text { Calibration } \\
\text { interval }\left(\mu \mathrm{g} \mathrm{L}^{-1}\right)\end{array}$} & \multirow{2}{*}{$\begin{array}{l}\text { Validity } \\
\text { interval }\left(\mu \mathrm{g} \mathrm{L}^{-1}\right)\end{array}$} & \multicolumn{2}{|c|}{ Recovery interval (\%) } \\
\hline & Instrumental step & Full method & & & Instrumental step & Full method \\
\hline Isoproturon & 20 & 0.030 & $20-500$ & $0.030-300$ & $75-130$ & $63-110$ \\
\hline Diuron & 20 & 0.030 & $20-500$ & $0.030-300$ & $82-128$ & $70-123$ \\
\hline 3,4-Dichloroaniline & 20 & 0.030 & $20-500$ & $0.030-300$ & $88-130$ & $47-106$ \\
\hline 4-Isopropylaniline & 20 & 0.030 & $20-500$ & $0.030-300$ & $80-130$ & $60-125$ \\
\hline Desethylatrazine & 20 & 0.030 & $20-500$ & $0.030-300$ & $76-130$ & $80-129$ \\
\hline Trifluralin & 20 & 0.015 & $20-500$ & $0.030-300$ & $70-130$ & $70-127$ \\
\hline Dimethoate & 20 & 0.030 & $50-500$ & $0.030-300$ & $66-124$ & $54-137$ \\
\hline Simazine & 50 & 0.030 & $20-500$ & $0.030-600$ & $75-135$ & $64-127$ \\
\hline Prometon & 20 & 0.030 & $20-500$ & $0.030-300$ & $76-124$ & $0-125$ \\
\hline Atrazine & 200 & 0.100 & $200-5000$ & $0.100-300$ & $78-130$ & $75-127$ \\
\hline Propazine & 20 & 0.015 & $20-500$ & $0.015-300$ & $86-130$ & $73-127$ \\
\hline Terbuthylazine & 20 & 0.015 & $20-500$ & $0.015-300$ & $79-130$ & $83-128$ \\
\hline Parathion methyl & 50 & 0.030 & $50-500$ & $0.030-300$ & $78-139$ & $72-130$ \\
\hline Parathion ethyl & 20 & 0.030 & $20-500$ & $0.030-300$ & $74-122$ & $64-128$ \\
\hline Alachlor & 20 & 0.015 & $20-500$ & $0.015-300$ & $75-125$ & $70-124$ \\
\hline Ametryn & 20 & 0.030 & $20-500$ & $0.030-300$ & $78-130$ & $0-116$ \\
\hline Prometryn & 20 & 0.030 & $20-500$ & $0.030-300$ & $80-120$ & $17-116$ \\
\hline Terbutryn & 20 & 0.030 & $20-500$ & $0.030-300$ & $80-120$ & $13-114$ \\
\hline Chlorpyrifos & 20 & 0.015 & $20-500$ & $0.015-300$ & $75-120$ & $73-116$ \\
\hline Chlorfenvinfos & 20 & 0.015 & $20-500$ & $0.015-300$ & $76-130$ & $70-126$ \\
\hline $\mathrm{HCHs}$ & 20 & 0.015 & $20-500$ & $0.015-300$ & $84-124$ & $70-120$ \\
\hline Hexachlorobenzene & 20 & 0.030 & $20-500$ & $0.030-300$ & $70-130$ & $74-136$ \\
\hline Heptachlor & 20 & 0.015 & $20-500$ & $0.015-300$ & $75-130$ & $58-113$ \\
\hline Heptachlor epoxide A & 20 & 0.015 & $20-500$ & $0.015-300$ & $85-125$ & $62-112$ \\
\hline Heptachlor epoxide B & 20 & 0.015 & $20-500$ & $0.015-300$ & $84-130$ & $58-113$ \\
\hline Aldrin & 20 & 0.015 & $20-500$ & $0.015-300$ & $85-125$ & $64-126$ \\
\hline 4,4'-Dichlorobenzophenone & 20 & 0.015 & $20-500$ & $0.015-300$ & $75-120$ & $68-126$ \\
\hline Isodrin & 20 & 0.015 & $20-500$ & $0.015-300$ & $85-125$ & $66-120$ \\
\hline$\alpha$-Endosulphan & 20 & 0.015 & $20-500$ & $0.015-300$ & $70-125$ & $70-93$ \\
\hline $\mathrm{pp}^{\prime}-\mathrm{DDE}$ & 20 & 0.015 & $20-500$ & $0.015-300$ & $89-122$ & $64-107$ \\
\hline Dieldrin & 20 & 0.015 & $20-500$ & $0.015-300$ & $70-125$ & $62-120$ \\
\hline Endrin & 20 & 0.015 & $20-500$ & $0.015-300$ & $80-125$ & $74-122$ \\
\hline $\mathrm{pp}^{\prime}-\mathrm{DDD}+\mathrm{op}^{\prime}-\mathrm{DDT}$ & 40 & 0.030 & $40-1000$ & $0.030-600$ & $79-125$ & $66-139$ \\
\hline Endosulphan-sulphate & 20 & 0.015 & $20-500$ & $0.015-300$ & $83-125$ & $73-126$ \\
\hline $\mathrm{pp}^{\prime}-\mathrm{DDT}$ & 20 & 0.030 & $20-500$ & $0.030-300$ & $76-130$ & $50-120$ \\
\hline Dicofol & 50 & 0.030 & $50-500$ & $0.030-300$ & $80-148$ & $63-136$ \\
\hline Methoxychlor & 20 & 0.015 & $20-500$ & $0.015-300$ & $77-126$ & $75-130$ \\
\hline Metholachlor & 20 & 0.015 & $20-500$ & $0.015-300$ & $76-115$ & $73-128$ \\
\hline Molinate & 20 & 0.015 & $20-500$ & $0.015-300$ & $91-130$ & $75-113$ \\
\hline Tetradifon & 20 & 0.015 & $20-500$ & $0.015-300$ & $85-130$ & $70-116$ \\
\hline
\end{tabular}

the effectiveness of photocatalytic treatment with hydrogen peroxide on the degradation of different compounds, or even on the generation of ROS: degradation of dyes [2730], pesticides [31,32], antibiotics [33], and ROS production [34]. In these tests, hydrogen peroxide was removed after the treatment.
The UV/VIS radiation source was provided using an ATLAS SUNTEST CPS+/XLS+ solar chamber. This chamber is an instrument equipped with a xenon lamp used for lighting and the ageing of materials. It can be used as simulator of natural sunlight. The chamber also includes an agitation system, a quartz filter, UV radiation, visible light, 
temperature control. It is equipped with a programmable system for measuring and for regulating the irradiation intensity. The irradiation range of the equipment is from 250 to $785 \mathrm{~W} \mathrm{~m}^{-2}$ with a wavelength of 300 to $800 \mathrm{~nm}$. The samples were subjected to a radiation intensity from $500 \mathrm{~W} \mathrm{~m}^{-2}$ which corresponds to $50 \%$ of the intensity of natural solar radiation at midday [35].

All the tests were performed in duplicate, using glass beakers of $1 \mathrm{~L}$ and with shaking. Moreover, blank tests were carried out.

\section{Results and Discussion}

The results of the two photocatalytic treatments $\left(\mathrm{TiO}_{2} / \mathrm{radi}\right.$ ation and $\mathrm{TiO}_{2} / \mathrm{H}_{2} \mathrm{O}_{2} /$ radiation) on the solutions of natural water fortified with the 44 pesticides under study relating to the sample characterization and the removal of pesticides are presented below.

3.1. Sample Characterization. The characterization of the initial sample and the samples treated with the two photocatalytic processes is shown in Table 4.

The results show the following.

(i) The application of photocatalytic treatments does not produce significant variations with respect to the initial values of $\mathrm{pH}$, conductivity, color, dissolved oxygen, hardness, ammonium concentration, and concentration of ions in solution.

(ii) The turbidity of the sample, in both cases, declines slightly, and solids in suspension make it significantly through the chemical oxidation of organic matter produced in the treatment.

(iii) Chlorine demand in the $\mathrm{TiO}_{2}$ /radiation-treated sample is reduced significantly, up to a value of of $1 \mathrm{mg} \mathrm{L}^{-1}$. However, the application of $\mathrm{TiO}_{2} / \mathrm{H}_{2} \mathrm{O}_{2} / \mathrm{ra}$ diation treatment produces an enormous increase in this parameter. This is possibly due to the various byproducts formed after the application.

(iv) Regarding the toxicity of treated sample, $\mathrm{TiO}_{2} /$ radiation treatment reduces the initial toxicity of the sample to approximately half its initial value. On the other hand, the application of $\mathrm{TiO}_{2} / \mathrm{H}_{2} \mathrm{O}_{2} /$ radiation produces an increase in the initial toxicity, due to the formation of byproducts more toxic than the original. This has occurred in other research works concerning the application of these photocatalytic treatments [14, 36-38].

(v) The COD undergoes no variation through the $\mathrm{TiO}_{2} /$ $\mathrm{H}_{2} \mathrm{O}_{2}$ /radiation treatment while it is reduced by $36 \%$ after the application of $\mathrm{TiO}_{2} /$ radiation. This suggests the mineralization of organic matter present in the process with hydrogen peroxide [39].

(vi) Suspended solids are removed by both photocatalytic treatments. This is due to the organic matter present in the water by this advanced oxidation process. (vii) Hydrogen peroxide appears after the $\mathrm{TiO}_{2} /$ radiation treatment formed as a by-product in photocatalytic reactions. In the case of the $\mathrm{TiO}_{2} / \mathrm{H}_{2} \mathrm{O}_{2} /$ radiation treatment, where it is used initially as a reagent, almost its total consumption is observed.

3.2. Pesticide Removal. Photocatalytic experiments were carried out in duplicate. Table 5 shows the average concentration of each pesticide studied in the initial sample and the final concentration after the photocatalytic treatments. It is worth noting that average concentrations are shown because the variations obtained in these analyses were very low, always below $2 \%$.

In addition to the photocatalytic treatments, blank tests were carried out. These blank tests were solution of pesticides with titanium dioxide without radiation and with radiation without catalyst. The results obtained are shown in Table 6. Only for some pesticides were degradations different to zero achieved.

As can be observed, some of the studied pesticides can be degraded by $\mathrm{TiO}_{2}$ without radiation and by radiation without $\mathrm{TiO}_{2}$. The degradation of these pesticides by $\mathrm{TiO}_{2}$ only is due to their adsorption in the catalyst. The degradation of these pesticides by radiation only is due to the advanced oxidation process with UV by which hydroxyl radicals are generated.

Table 7 shows the average removal percentages of the pesticides.

The photocatalytic treatments achieved an average degradation of $48 \%$ by photocatalysis $\left(\mathrm{TiO}_{2} /\right.$ radiation) and $57 \%$ by photocatalysis with hydrogen peroxide $\left(\mathrm{TiO}_{2} / \mathrm{H}_{2} \mathrm{O}_{2} /\right.$ radiation).

The photocatalytic treatments were very effective in the removal of parathion methyl, chlorpyrifos, $\alpha$-endosulphan, 3,4-dichloroaniline, 4-isopropylaniline, and dicofol. The treatments were less effective in the degradation of $\mathrm{HCHs}$, endosulphan-sulphate, heptachlors epoxide, and 4,4'-dichlorobenzophenone.

As can be seen in Tables 5 and 7, the addition of hydrogen peroxide to the process slightly improves the average percentage of pesticide removal. However, this improvement does not occur for all the pesticides studied. In fact, some of them present the same removal percentages by both photocatalytic treatments. The increase in the average percentage of degradation is due to an improvement in some of the studied pesticides to add hydrogen peroxide. These are some triazines, $\alpha$-endosulphan, molinate, trifluralin, and anilides, for which removal is improved by 5-20\% using hydrogen peroxide; isodrin, aldrin, DDTs, and 4,4'-dichlorobenzophenone, for which removal is improved by $25-50 \%$ using hydrogen peroxide.

The degradation percentages of the pesticides in their individual group are as follows.

Triazines. The rates of degradation of triazines obtained by the photocatalytic treatments are between 35 and $60 \%$. By photocatalysis, these percentages are from 35 to $55 \%$. Degradation of these pesticides is very similar, $40-60 \%$, when 
TABLE 4: Characterization of samples of surface wáter fortified with pesticides in photocatalytic treatments.

\begin{tabular}{|c|c|c|c|}
\hline \multicolumn{4}{|c|}{ Initial sample } \\
\hline \multicolumn{4}{|c|}{ Physical-chemical parameters } \\
\hline $\mathrm{pH}$ & 8.0 & Colour (PCU) & 0 \\
\hline Conductivity $\left(\mu \mathrm{S} \mathrm{cm}^{-1}\right)$ & 508 & Dissolved oxygen $\left(\mathrm{mg} \mathrm{L}^{-1}\right)$ & 9.9 \\
\hline Turbidity (NTU) & 69 & Hardness $\left(\mathrm{mg} \mathrm{CaCO}_{3} \mathrm{~L}^{-1}\right)$ & 108 \\
\hline Suspended solids $\left(\mathrm{mg} \mathrm{L}^{-1}\right)$ & 27 & $\mathrm{NH}_{4}^{+}$concentration $\left(\mathrm{mg} \mathrm{L}^{-1}\right)$ & 0.15 \\
\hline Phosphorous (mg L $\left.\mathrm{m}^{-1}\right)$ & 0.8 & $\mathrm{CN}^{-}$concentration $\left(\mathrm{mg} \mathrm{L}^{-1}\right)$ & 0.002 \\
\hline $\mathrm{DOC}\left(\mathrm{mg} \mathrm{C} \mathrm{L}^{-1}\right)$ & 22 & Toxicity (\% inhibition) & 33.6 \\
\hline Chlorine demand $\left(\mathrm{mg} \mathrm{Cl}_{2} \mathrm{~L}^{-1}\right)$ & & 6.0 & \\
\hline \multicolumn{4}{|c|}{ Anion concentrations in solution $\left(\mathrm{mg} \mathrm{L}^{-1}\right)$} \\
\hline Fluorides & 0.1 & Nitrates & 10.8 \\
\hline Chlorides & 63.8 & Phosphates & $<0.2$ \\
\hline Sulphates & & 98 & \\
\hline \multicolumn{4}{|c|}{ Sample after treatment $\mathrm{TiO}_{2} /$ radiation } \\
\hline \multicolumn{4}{|c|}{ Physical-chemical parameters } \\
\hline $\mathrm{pH}$ & 8.0 & Colour (PCU) & 0 \\
\hline Conductivity $\left(\mu \mathrm{S} \mathrm{cm}^{-1}\right)$ & 589 & Dissolved oxygen $\left(\mathrm{mg} \mathrm{L}^{-1}\right)$ & 6.2 \\
\hline Turbidity (NTU) & 54 & Hardness $\left(\mathrm{mg} \mathrm{CaCO}_{3} \mathrm{~L}^{-1}\right)$ & 109 \\
\hline Suspended solids $\left(\mathrm{mg} \mathrm{L}^{-1}\right)$ & 7 & $\mathrm{NH}_{4}^{+}$concentration $\left(\mathrm{mg} \mathrm{L}^{-1}\right)$ & 0.15 \\
\hline Phosphorous (mg L ${ }^{-1}$ ) & 0.4 & $\mathrm{CN}^{-}$concentration $\left(\mathrm{mg} \mathrm{L}^{-1}\right)$ & 0.0015 \\
\hline $\mathrm{DOC}\left(\mathrm{mg} \mathrm{C} \mathrm{L}^{-1}\right)$ & 14 & Toxicity (\% inhibition) & 18.9 \\
\hline $\mathrm{H}_{2} \mathrm{O}_{2}$ concentration $\left(\mathrm{mg} \mathrm{L}^{-1}\right)$ & 5 & Chlorine demand $\left(\mathrm{mg} \mathrm{Cl}_{2} \mathrm{~L}^{-1}\right)$ & 1.0 \\
\hline \multicolumn{4}{|c|}{ Anion concentrations in solution $\left(\mathrm{mg} \mathrm{L}^{-1}\right)$} \\
\hline Fluorides & $<0.1$ & Nitrates & 11.6 \\
\hline Chlorides & 66.4 & Phosphates & $<0.2$ \\
\hline Sulphates & & 101.0 & \\
\hline \multicolumn{4}{|c|}{ Sample after treatment $\mathrm{TiO}_{2} / \mathrm{H}_{2} \mathrm{O}_{2} /$ radiation } \\
\hline \multicolumn{4}{|c|}{ Physical-chemical parameters } \\
\hline $\mathrm{pH}$ & 8.0 & Colour (PCU) & 0 \\
\hline Conductivity $\left(\mu \mathrm{S} \mathrm{cm}^{-1}\right)$ & 625 & Dissolved oxygen $\left(\mathrm{mg} \mathrm{L}^{-1}\right)$ & 9.8 \\
\hline Turbidity (NTU) & 56 & Hardness $\left(\mathrm{mg} \mathrm{CaCO} 3 \mathrm{~L}^{-1}\right)$ & 95 \\
\hline Suspended solids ( $\left.\mathrm{mg} \mathrm{L}^{-1}\right)$ & 5 & $\mathrm{NH}_{4}{ }^{+}$concentration $\left(\mathrm{mg} \mathrm{L}^{-1}\right)$ & 0.15 \\
\hline Phosphorous (mg L ${ }^{-1}$ ) & 0.2 & $\mathrm{CN}^{-}$concentration $\left(\mathrm{mg} \mathrm{L}^{-1}\right)$ & 0.001 \\
\hline $\mathrm{DOC}\left(\mathrm{mg} \mathrm{C} \mathrm{L}{ }^{-1}\right)$ & 22 & Toxicity (\% inhibition) & 43.3 \\
\hline $\mathrm{H}_{2} \mathrm{O}_{2}$ concentration $\left(\mathrm{mg} \mathrm{L}^{-1}\right)$ & 0.5 & Chlorine demand $\left(\mathrm{mg} \mathrm{Cl}_{2} \mathrm{~L}^{-1}\right)$ & 55.6 \\
\hline \multicolumn{4}{|c|}{ Anion concentrations in solution $\left(\mathrm{mg} \mathrm{L}^{-1}\right)$} \\
\hline Fluorides & $<0.1$ & Nitrates & 11.4 \\
\hline Chlorides & 65.0 & Phosphates & $<0.2$ \\
\hline Sulphates & & 99.2 & \\
\hline
\end{tabular}

hydrogen peroxide is added to the treatment. Therefore, the addition of this reagent is not compensated for by the increase of the effectiveness in the degradation of triazines by photocatalytic treatment. Among the triazines studied are atrazine and desethylatrazine, the most difficult to degrade by photocatalytic treatments.

Organic Phosphorated. The five organic-phosphorated pesticides studied are degraded between 40 and $90 \%$ by photocatalytic treatments. The degradation percentages obtained for these pesticides are similar whether or not hydrogen peroxide is added. The degradation of dimethoate and chlorfenvinfos only slightly improves when hydrogen peroxide is added. Methyl parathion and chlorpyrifos are the pesticides that degrade best by photocatalysis (degradation of $80-$ $90 \%$ ) while chlorfenvinfos is the most difficult organicphosphorated pesticide to degrade (maximum degradation of $55 \%$ ).

$\mathrm{HCH}$ s and $\mathrm{HCB}$. With regard to $\mathrm{HCHs}$, the degradation percentages obtained by the photocatalytic treatments are the lowest. In all cases, adding hydrogen peroxide makes 
TABLE 5: Concentration of pesticides in samples in photocatalytic treatments.

\begin{tabular}{|c|c|c|c|}
\hline \multirow{2}{*}{ Pesticide } & \multicolumn{3}{|c|}{ Concentration $\left(\mathrm{ng} \mathrm{L}^{-1}\right)$} \\
\hline & Initial & After $\mathrm{TiO}_{2} /$ radiation & After $\mathrm{TiO}_{2} / \mathrm{H}_{2} \mathrm{O}_{2} /$ radiation \\
\hline Alachlor & 505 & 253 & 177 \\
\hline Aldrin & 512 & 230 & 26 \\
\hline Ametryn & 501 & 225 & 225 \\
\hline Atrazine & 551 & 358 & 331 \\
\hline Chlorfenvinfos & 492 & 295 & 221 \\
\hline Chlorpyrifos & 520 & 104 & 104 \\
\hline $\mathrm{pp}^{\prime}-\mathrm{DDD}$ & 510 & 332 & 102 \\
\hline $\mathrm{op}^{\prime}-\mathrm{DDE}$ & 480 & 288 & 144 \\
\hline $\mathrm{op}^{\prime}-\mathrm{DDT}$ & 482 & 313 & 96 \\
\hline $\mathrm{pp}^{\prime}-\mathrm{DDT}$ & 482 & 386 & 145 \\
\hline Desethylatrazine & 593 & 385 & 356 \\
\hline 3,4-Dichloroaniline & 658 & 0 & 0 \\
\hline 4,4'-Dichlorobenzophenone & 519 & 493 & 363 \\
\hline Dicofol & 568 & 57 & 57 \\
\hline Dieldrin & 508 & 356 & 356 \\
\hline Dimethoate & 608 & 274 & 243 \\
\hline Diuron & 501 & 125 & 125 \\
\hline$\alpha$-Endosulphan & 475 & 48 & 0 \\
\hline Endosulphan-sulphate & 483 & 459 & 435 \\
\hline Endrin & 486 & 243 & 243 \\
\hline$\alpha-\mathrm{HCH}$ & 511 & 109 & 409 \\
\hline$\beta-\mathrm{HCH}$ & 519 & 441 & 441 \\
\hline$\gamma-\mathrm{HCH}$ & 521 & 443 & 417 \\
\hline$\delta-\mathrm{HCH}$ & 504 & 428 & 428 \\
\hline Heptachlor & 491 & 246 & 246 \\
\hline Heptachlor epoxide A & 495 & 347 & 347 \\
\hline Heptachlor epoxide B & 487 & 341 & 341 \\
\hline Hexachlorobenzene & 503 & 327 & 327 \\
\hline Isodrin & 516 & 206 & 0 \\
\hline 4-Isopropylaniline & 512 & 0 & 0 \\
\hline Isoproturon & 521 & 78 & 78 \\
\hline Metholachlor & 524 & 262 & 210 \\
\hline Methoxychlor & 519 & 234 & 130 \\
\hline Molinate & 551 & 248 & 165 \\
\hline Parathion ethyl & 507 & 228 & 228 \\
\hline Parathion methyl & 508 & 51 & 51 \\
\hline Prometon & 492 & 271 & 271 \\
\hline Prometryn & 489 & 220 & 220 \\
\hline Propazine & 508 & 330 & 305 \\
\hline Simazine & 554 & 305 & 277 \\
\hline Terbuthylazine & 524 & 262 & 262 \\
\hline Terbutryn & 514 & 231 & 206 \\
\hline Tetradifon & 493 & 296 & 296 \\
\hline Trifluralin & 566 & 255 & 170 \\
\hline
\end{tabular}

no difference to the degradation percentages obtained so its use is redundant. The HCB is degraded $35 \%$ by the photocatalyisis, and the addition of hydrogen peroxide does not produce any improvement.
Heptachlors. Degradation rates obtained for the heptachlors are $50 \%$ while the heptachlors epoxides are more difficult to degrade $(30 \%)$. The addition of hydrogen peroxide to the process does not improve the degradation percentages 
TABLE 6: Degradation of pesticides in blank experiments.

\begin{tabular}{lcc}
\hline Pesticide & Removal by $\mathrm{TiO}_{2}$ & Removal by radiation \\
\hline Trifluralin & 0 & 28 \\
Heptachlor & 14 & 45 \\
Aldrin & 20 & 50 \\
Isodrin & 24 & 55 \\
$\mathrm{pp}^{\prime}$-DDE & 33 & 46 \\
$\mathrm{pp}^{\prime}$-DDD $+\mathrm{op}^{\prime}$-DDT & 21 & 13 \\
$\mathrm{pp}^{\prime}$-DDT & 25 & 28 \\
\hline
\end{tabular}

of these pesticides. In case of heptachlors, the blanks experiments show a degradation of $45 \%$ by radiation. The photocatalytic treatment does not therefore improve its degradation with respect to radiation only.

Endosulphans. Under photocatalysis, $\alpha$-endosulphan shows almost total degradation while endosulphan-sulphate is practically undegraded by photocatalytic treatments. Both have the same behavior after the addition of hydrogen peroxide, showing an improvement of 5\%, although again this small improvement does not compensate for its use.

Drins. With regard to these pesticides, it can be seen by these treatments that aldrin and isodrin (isomers between them) are more easily degradable that endrin and dieldrin (isomers between them), especially in the case of using hydrogen peroxide. The rates of degradation of dieldrin and endrin, $50 \%$ and $30 \%$ respectively, do not improve when adding hydrogen peroxide. In the case of aldrin and isodrin, blank experiments show an important degradation by radiation. Thus radiation and not the photocatalytic treatment is responsible for their degradation. However, the degradation of aldrin and isodrin is noticeably more effective when using hydrogen peroxide treatment, achieving their complete degradation.

DDTs. The DDTs studied degrade between 20\% and 40\% under the photocatalytic treatments. However, similar degradations are achieved in the blank experiments. The degradation could thus occur by the effect of titanium dioxide or radiation only, not by photocatalytic treatment. These degradation rates increase significantly by adding hydrogen peroxide, reaching $70-80 \%$. Therefore, for the DDTs the presence of hydrogen peroxide notably favours their degradation.

Anilines. The two studied anilines, 3,4-dichloroaniline and 4 -isopropylaniline, are completely degraded by the photocatalytic treatments. Therefore, the use of hydrogen peroxide is not necessary for increasing the effectiveness of the treatment.

Ureas. Isoproturon and diuron, the studied pesticides that are derivatives of urea, present high degradation rates under the photocatalytic treatments, being $85 \%$ and $75 \%$, respectively. The same percentages are obtained when using hydrogen peroxide, so that its use does not improve the process.

Anilides. The three anilides studied also show the same behaviour with photocatalytic treatments, and the addition of hydrogen peroxide produces a slight improvement, from $5 \%$ to $20 \%$. Under photocatalysis, the degradation percentages are $50-55 \%$. These percentages increase slightly when hydrogen peroxide is added to the treatment system, achieving rates of $60-75 \%$ degradation in this case.

Other Pesticides. For the rest of the pesticides under study, molinate, trifluralin, tetradiphon, dicofol, and 4,4'-dichlorobenzophenone, very different degradations are achieved. Molinate and trifluralin are degraded $55 \%$ by the photocatalysis and this percentage increases to $70 \%$ when hydrogen peroxide is added. Therefore, the use of this reagent represents a significant improvement in the degradation of these two pesticides. In the case of trifluralin, the blank experiment with radiation produced $30 \%$ degradation but its removal is greater by photocatalysis. Degradation of dicofol is very effective by the photocatalytic treatment, being $90 \%$. The presence of hydrogen peroxide does not favour degradation in this case. The same applies to tetradiphon, which degrades to a lesser extent (40\%), but hydrogen peroxide does not increase the effectiveness of the process. The 4,4' -dichlorobenzophenone is barely degraded at all by photocatalysis but its degradation increases up to $30 \%$ when adding hydrogen peroxide to the treatment.

\section{Conclusions}

After the completion of this study, the following conclusions can be drawn.

(i) The pesticides most effectively removed by the photocatalytic treatments, reaching yields higher than $80 \%$, are parathion methyl, $\alpha$-endosulphan, chlorpyrifos, 3,4-dichloroaniline, 4-isopropylaniline, and dicofol. The least degraded, below $30 \%$, are $\mathrm{HCHs}$, endosulphan-sulphate, heptachlors epoxides, and 4,4'-dichlorobenzophenone.

(ii) Photocatalytic treatment, $\mathrm{TiO}_{2} /$ radiation, achieves a partial removal of the studied pesticides of $48 \%$. When hydrogen peroxide is added the average percentage increases to $57 \%$. The addition of hydrogen peroxide improves the degradation of some of the pesticides studied, mainly isodrin, aldrin, DDTs, $4,4^{\prime}$ dichlorobenzophenone, some triazines, molinate, $\alpha$ endosulphan, trifluralin, and anilides.

(iii) $\mathrm{TiO}_{2} /$ radiation treatment produces a reduction of $36 \%$ of the initial COD, $43 \%$ of the initial toxicity, and chlorine demand is reduced to $1 \mathrm{mg} \mathrm{L}^{-1}$. The same treatment with hydrogen peroxide produces a large increase in toxicity and chlorine demand of the treated sample and there is no variation in the COD due to the generation of intermediate compounds 
TABLe 7: \% Removal of pesticides by photocatalytic treatments.

\begin{tabular}{|c|c|c|c|}
\hline Group & Pesticide & Removal after $\mathrm{TiO}_{2} /$ radiation (\%) & Removal after $\mathrm{TiO}_{2} / \mathrm{H}_{2} \mathrm{O}_{2} /$ radiation (\%) \\
\hline \multirow{9}{*}{ Triazines } & Simazine & 45 & 50 \\
\hline & Atrazine & 35 & 40 \\
\hline & Propazine & 35 & 40 \\
\hline & Terbuthylazine & 50 & 50 \\
\hline & Prometon & 45 & 45 \\
\hline & Ametryn & 55 & 55 \\
\hline & Prometryn & 55 & 55 \\
\hline & Terbutryn & 55 & 60 \\
\hline & Desethylatrazine & 35 & 40 \\
\hline \multirow{5}{*}{ Organic phosphorated } & Parathion methyl & 90 & 90 \\
\hline & Parathion ethyl & 55 & 55 \\
\hline & Chlorpyrifos & 80 & 80 \\
\hline & Chlorfenvinfos & 40 & 55 \\
\hline & Dimethoate & 55 & 60 \\
\hline \multirow{4}{*}{$\mathrm{HCHs}$} & $\alpha-\mathrm{HCH}$ & 20 & 20 \\
\hline & $\beta-\mathrm{HCH}$ & 15 & 15 \\
\hline & $\chi-\mathrm{HCH}$ & 15 & 20 \\
\hline & $\delta-\mathrm{HCH}$ & 15 & 15 \\
\hline $\mathrm{HCB}$ & Hexachlorobenzene & 35 & 35 \\
\hline \multirow{3}{*}{ Heptachlors } & Heptachlor & 50 & 50 \\
\hline & Heptachlor epoxide A & 30 & 30 \\
\hline & Heptachlor epoxide B & 30 & 30 \\
\hline \multirow{2}{*}{ Endosulphans } & $\alpha$-Endosulphan & 90 & 100 \\
\hline & Endosulphan-sulphate & 5 & 10 \\
\hline \multirow{4}{*}{ Drins } & Endrin & 50 & 50 \\
\hline & Dieldrin & 30 & 30 \\
\hline & Isodrin & 60 & 100 \\
\hline & Aldrin & 55 & 95 \\
\hline \multirow{3}{*}{ DDTs } & $\mathrm{pp}^{\prime}-\mathrm{DDE}$ & 40 & 70 \\
\hline & $\mathrm{pp}^{\prime}-\mathrm{DDD}+\mathrm{op}^{\prime}-\mathrm{DDT}$ & 35 & 80 \\
\hline & $\mathrm{pp}^{\prime}-\mathrm{DDT}$ & 20 & 70 \\
\hline \multirow{2}{*}{ Anilines } & 3,4-Dichloroaniline & 100 & 100 \\
\hline & 4-Isopropylaniline & 100 & 100 \\
\hline \multirow{2}{*}{ Ureas } & Isoproturon & 85 & 85 \\
\hline & Diuron & 75 & 75 \\
\hline Carbamate & Molinate & 55 & 70 \\
\hline Nitroderivate & Trifluralin & 55 & 70 \\
\hline \multirow{3}{*}{ Anilides } & Alachlor & 50 & 65 \\
\hline & Metholachlor & 50 & 60 \\
\hline & Methoxychlor & 55 & 75 \\
\hline \multirow{2}{*}{ Chlorophenols } & Tetradiphon & 40 & 40 \\
\hline & Dicofol & 90 & 90 \\
\hline Chlorinated diphenyl & 4,4'-Dichlrobenzophenone & 5 & 30 \\
\hline \multicolumn{2}{|c|}{ Average } & 48 & 57 \\
\hline
\end{tabular}

(no mineralization) that can be more toxic than the original.

(iv) Both the studied photocatalytic processes produce a reduction of turbidity and of the solids in suspension in the treated samples.

\section{Acknowledgments}

The authors wish to thank "MICINN-FEDER" for financing this paper through the project "Regeneración de aguas depuradas mediante procesos de oxidación avanzada (CTM200801876/TECNO)." 


\section{References}

[1] "Royal Decree 140/2003 de 7 de febrero, por el que se establecen los criterios sanitarios de la calidad del agua de consumo humano," BOE 54 de 21 de febrero de 2003.

[2] Royal Decree 1620/2007 of 7 December 2007, which establishes the legal category for the reuse of purified water, Bulletin Official of the State 294, of 8 December 2007.

[3] "Directive 2008/105/EC of the European Parliament and of the Council of 16 December 2008, on environmental quality standards in the field of water policy, amending and subsequently repealing Council Directives 82/176/EEC, 83/513/ EEC, 84/156/EEC, 84/491/EEC, 86/280/EEC and amending Directive 2000/60/EC of the European Parliament and of the Council," Official Journal of the European Union L 348/84, 2008.

[4] G. R. Peyton and W. H. Glaze, "Destruction of pollutants in water with ozone in combination with ultraviolet radiation. 3 . Photolysis of aqueous ozone," Environmental Science and Technology, vol. 22, no. 7, pp. 761-767, 1988.

[5] S. J. Masten and S. H. R. Davies, "The use of ozonation to degrade organic contaminants in wastewaters," Environmental Science Technology, vol. 28, no. 4, pp. 181A-185A, 1994.

[6] E. Evgenidou, E. Bizani, C. Christophoridis, and K. Fytianos, "Heterogeneous photocatalytic degradation of prometryn in aqueous solutions under UV-Vis irradiation," Chemosphere, vol. 68 , no. 10, pp. 1877-1882, 2007.

[7] S. Sanches, M. T. Barreto Crespo, and V. J. Pereira, "Drinking water treatment of priority pesticides using low pressure UV photolysis and advanced oxidation processes," Water Research, vol. 44, no. 6, pp. 1809-1818, 2010.

[8] S. F. Chen, Z. Mengyue, and T. Yaowu, "Photocatalytic degradation of organophosphorous pesticides using $\mathrm{TiO}_{2}$ supported on fiberglass," Journal of Microchemistry, vol. 54, pp. 54-58, 1996.

[9] P. Oancea and T. Oncescu, "The photocatalytic degradation of dichlorvos under solar irradiation," Journal of Photochemistry and Photobiology A, vol. 199, no. 1, pp. 8-13, 2008.

[10] L. Wei, C. Shifu, Z. Wei, and Z. Sujuan, "Titanium dioxide mediated photocatalytic degradation of methamidophos in aqueous phase," Journal of Hazardous Materials, vol. 164, no. 1, pp. 154-160, 2009.

[11] P. N. Moza, K. Hustert, S. Pal, and P. Sukul, "Photocatalytic decomposition of pendimethalin and alachlor," Chemosphere, vol. 25, no. 11, pp. 1675-1682, 1992.

[12] C. C. Wong and W. Chu, "The direct photolysis and photocatalytic degradation of alachlor at different $\mathrm{TiO}_{2}$ and UV sources," Chemosphere, vol. 50, no. 8, pp. 981-987, 2003.

[13] A. E. Kinkennon, D. B. Green, and B. Hutchinson, "The use of simulated or concentrated natural solar radiation for the $\mathrm{TiO}_{2}$-mediated photodecomposition of basagran, diquat, and diuron," Chemosphere, vol. 31, no. 7, pp. 8663-8671, 1995.

[14] T. S. Kim, J. K. Kim, K. Choi, M. K. Stenstrom, and K. D. Zoh, "Degradation mechanism and the toxicity assessment in $\mathrm{TiO}_{2}$ photocatalysis and photolysis of parathion," Chemosphere, vol. 62, no. 6, pp. 926-933, 2006.

[15] O. Borio, B. M. Gawlik, I. R. Bellobono, and H. Muntau, "Photooxidation of prometryn and prometon in aqueous solution by hydrogen peroxide on photocatalytic membranes immobilising titanium dioxide," Chemosphere, vol. 37, no. 5, pp. 975989, 1998.

[16] E. Pelizzetti, "Concluding remarks on heterogeneous solar photocatalysis," Solar Energy Materials and Solar Cells, vol. 38, no. $1-4$, pp. $453-457,1995$.
[17] S. Malato, P. Fernández-Ibáñez, M. I. Maldonado, J. Blanco, and W. Gernjak, "Decontamination and disinfection of water by solar photocatalysis: recent overview and trends," Catalysis Today, vol. 147, no. 1, pp. 1-59, 2009.

[18] A. D. Eaton, L. S. Clesceri, E. W. Rice, A. E. Greenberg, and M. A. H. Franson, Standard Methods for the Examination of Water and Wastewater, 21st edition, 2005.

[19] UNE-EN Norm 27888:1994. Determinación de la conductividad eléctrica (ISO 7888:1985). Ediciones AENOR.

[20] ISO Norm 7027:1999. Water quality. Determination of turbidity.

[21] R. F. P. Nogueira, C. O. Mirela, and W. C. Paterlini, "Simple and fast spectrophotometric determination of $\mathrm{H}_{2} \mathrm{O}_{2}$ in photoFenton reactions using metavanadate," Talanta, vol. 66, pp. 86-91, 2005.

[22] ISO Norm 11348:1999. Water quality. Determination of the inhibitory effect of water samples on the light emission of Vibrio fischeri (Luminescent bacteria test).

[23] EPA Method 525.2. Determination of organic compounds in drinking water by liquid-solid extraction and capillary column gas chromatography/mass spectrometry-Revision 2.0.

[24] A. G. Rincón and C. Pulgarín, "Photocatalytical inactivation of E. coli: effect of (continuous-intermittent) light intensity and of (suspended-fixed) $\mathrm{TiO}_{2}$ concentration," Applied Catalysis B, vol. 44, no. 3, pp. 263-284, 2003.

[25] H. M. Coleman, C. P. Marquis, J. A. Scott, S. S. Chin, and R. Amal, "Bactericidal effects of titanium dioxide-based photocatalysts," Chemical Engineering Journal, vol. 113, no. 1, pp. 55-63, 2005.

[26] M. Lanao, M. P. Ormad, C. Ibarz, N. Miguel, and J. L. Ovelleiro, "Bactericidal effectiveness of $\mathrm{O}_{3}, \mathrm{O}_{3} / \mathrm{H}_{2} \mathrm{O}_{2}$ and $\mathrm{O}_{3} /$ $\mathrm{TiO}_{2}$ on Clostridium perfringens," Ozone Science \& Technology, vol. 30, no. 6, pp. 431-438, 2008.

[27] A. Riga, K. Soutsas, K. Ntampegliotis, V. Karayannis, and G. Papapolymerou, "Effect of system parameters and of inorganic salts on the decolorization and degradation of Procion $\mathrm{H}$-exl dyes. Comparison of $\mathrm{H}_{2} \mathrm{O}_{2} / \mathrm{UV}$, Fenton, UV/Fenton, $\mathrm{TiO}_{2} / \mathrm{UV}$ and $\mathrm{TiO}_{2} / \mathrm{UV} / \mathrm{H}_{2} \mathrm{O}_{2}$ processes," Desalination, vol. 211, no. 1-3, pp. 72-86, 2007.

[28] M. Saquib, M. Abu Tariq, M. Faisal, and M. Muneer, "Photocatalytic degradation of two selected dye derivatives in aqueous suspensions of titanium dioxide," Desalination, vol. 219, no. 1-3, pp. 301-311, 2008.

[29] N. Sobana, K. Selvam, and M. Swaminathan, "Optimization of photocatalytic degradation conditions of Direct Red 23 using nano-Ag doped $\mathrm{TiO}_{2}$," Separation and Purification Technology, vol. 62, no. 3, pp. 648-653, 2008.

[30] J. C. Garcia, J. I. Simionato, A. E. C. D. Silva, J. Nozaki, and N. E. D. Souza, "Solar photocatalytic degradation of real textile effluents by associated titanium dioxide and hydrogen peroxide," Solar Energy, vol. 83, no. 3, pp. 316-322, 2009.

[31] M. Qamar, M. Muneer, and D. Bahnemann, "Heterogeneous photocatalysed degradation of two selected pesticide derivatives, triclopyr and daminozid in aqueous suspensions of titanium dioxide," Journal of Environmental Management, vol. 80, no. 2, pp. 99-106, 2006.

[32] W. Bahnemann, M. Muneer, and M. M. Haque, "Titanium dioxide-mediated photocatalysed degradation of few selected organic pollutants in aqueous suspensions," Catalysis Today, vol. 124, no. 3-4, pp. 133-148, 2007.

[33] M. M. Haque and M. Muneer, "Photodegradation of norfloxacin in aqueous suspensions of titanium dioxide," Journal of Hazardous Materials, vol. 145, no. 1-2, pp. 51-57, 2007. 
[34] B. G. Kwon, "Characterization of the hydroperoxy/superoxide anion radical formed from the photolysis of inmobilized $\mathrm{TiO}_{2}$ in a continuous flow," Journal of Photochemistry and Photobiology A, vol. 199, pp. 112-118, 2008.

[35] T. Yuranova, O. Enea, E. Mielczarski, J. Mielczarski, P. Albers, and J. Kiwi, "Fenton immobilized photo-assisted catalysis through a Fe/C structured fabric," Applied Catalysis B, vol. 49, no. 1, pp. 39-50, 2004.

[36] A. Bozzi, M. Dhananjeyan, I. Guasaquillo et al., "Evolution of toxicity during melamine photocatalysis with $\mathrm{TiO}_{2}$ suspensions," Journal of Photochemistry and Photobiology A, vol. 162, no. 1, pp. 179-185, 2004.

[37] E. C. Catalkaya and F. Kargi, "Advanced oxidation treatment of pulp mill effluent for TOC and toxicity removals," Journal of Environmental Management, vol. 87, no. 3, pp. 396-404, 2008.

[38] V. A. Sakkas, P. Calza, M. A. Islam et al., " $\mathrm{TiO}_{2} / \mathrm{H}_{2} \mathrm{O}_{2}$ mediated photocatalytic transformation of UV filter 4-methylbenzylidene camphor (4-MBC) in aqueous phase: statistical optimization and photoproduct analysis," Applied Catalysis B, vol. 90, no. 3-4, pp. 526-534, 2009.

[39] I. K. Konstantinou and T. A. Albanis, "Photocatalytic transformation of pesticides in aqueous titanium dioxide suspensions using artificial and solar light: intermediates and degradation pathways," Applied Catalysis B, vol. 42, no. 4, pp. 319-335, 2003. 




International Journal of

Medicinal Chemistry

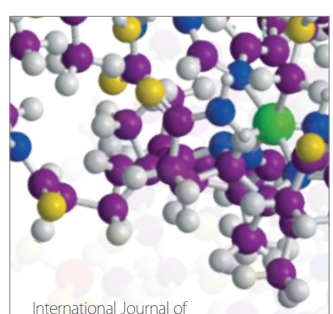

Carbohydrate Chemistry

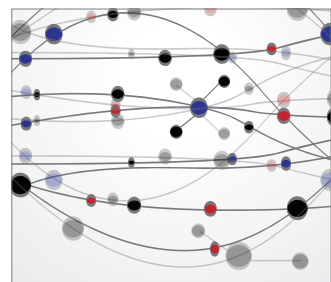

The Scientific World Journal
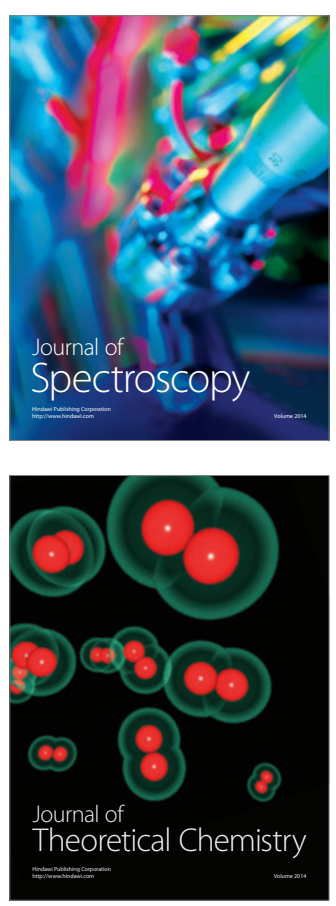
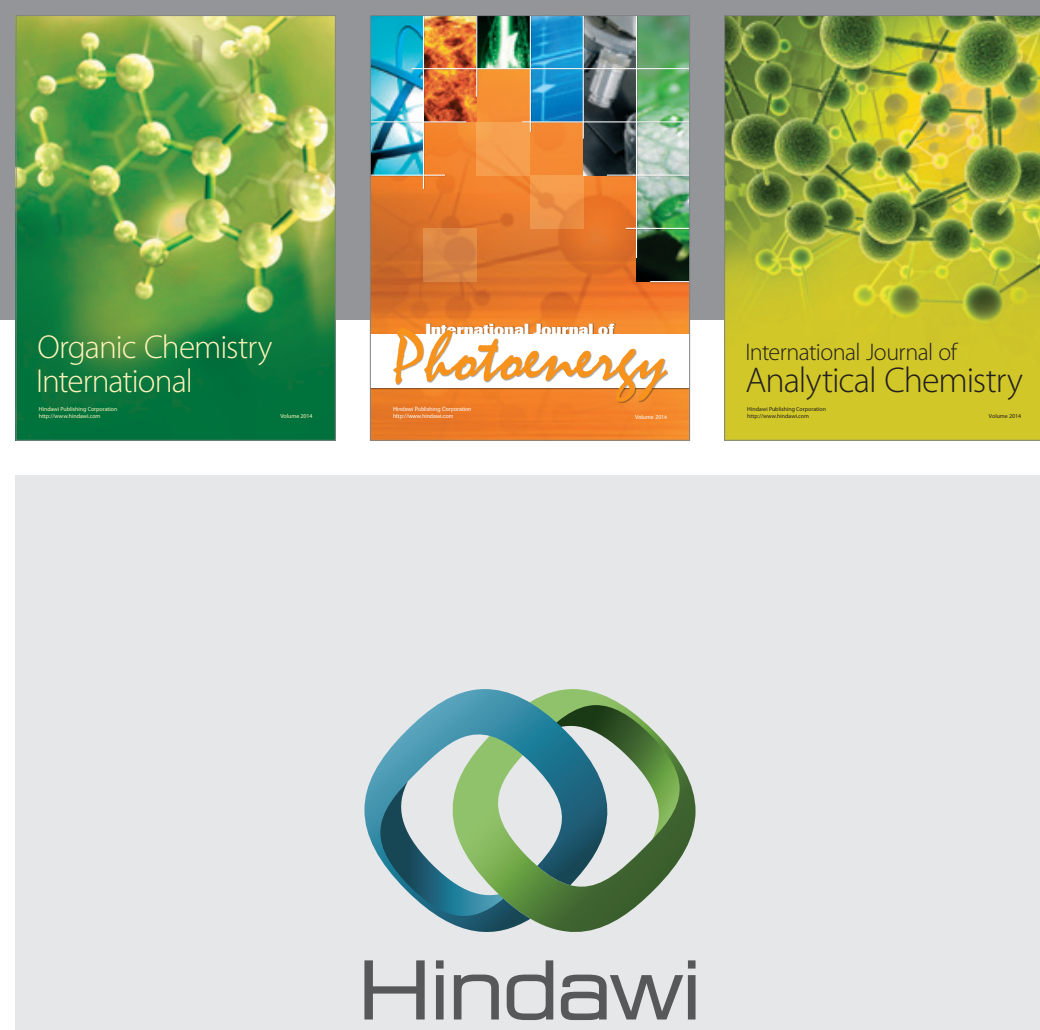

Submit your manuscripts at

http://www.hindawi.com
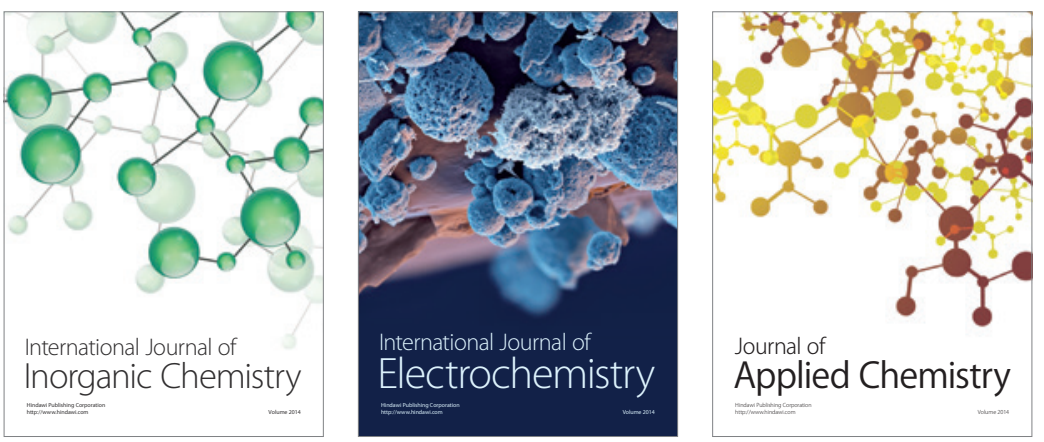

Journal of

Applied Chemistry
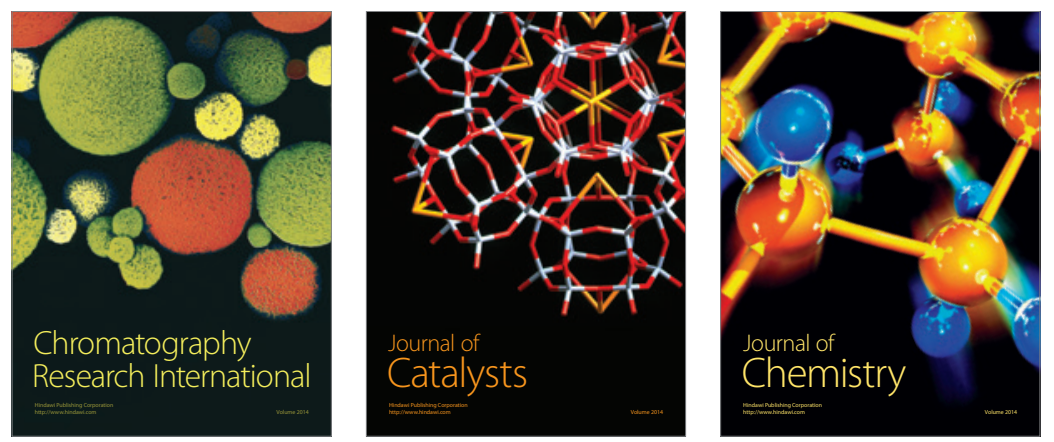
